\title{
Is Javanese still Vital in Plurilingual Societies of Karimunjawa?
}

\author{
Deli Nirmala \\ Faculty of Humanities, Diponegoro University \\ deliundip@gmail.com
}

\begin{abstract}
This paper aims at showing the vitality of Javanese in plurilingual societies in Karimunjawa. Karimunjawa is inhabited by fishermen from different ethnic groups like Maduranese, Buginese, Mandar. Observation, questionnaire, and interview with recording techniques were used to collect the data. The respondents are the students of Safinatul Huda junior and senior high schools and their parents who are interethnic marriage, living in Kemujan island. They were selected based on the availability principle that is due to their agreement for being interviewed. Besides, some interethnic-married couple in Karimunjawa were also interviewed, who were mostly aged citizens. Inferential method was used to analyzed data. The result indicates that Javanese is still actively used at home, schools, and mosques. Javanese is also learnt by non Javanese. They use Javanese since Javanese is the dominating one in Karimunjawa. There is a tendency that non-Javanese is shifting to Javanese and bahasa Indonesia, while Javanese is shifting to bahasa Indonesia. This indicates that Javanese is still strong even some of the non-Javanese tends to use Javanese not only its language but also its tradition like wedding ceremony.
\end{abstract}

Key words: plurilingual; Karimunjawa; shift; Javanese; interethnic marriage

\section{INTRODUCTION}

Javanese as the biggest local language in Indonesia has been studied by many experts who show different facts about it. Some of them found that Javanese is still strong and some others found that it is changing. Purwoko (2011) says that Javanese is still strong in ngoko speech level, that is the lowest speech level in Javanese. It is used in communication among friends or in colloquial situation. Purwoko also said that the higher speech level in Javanese that is krama is changing into basa which can indicate ngoko and krama characteristics. They are mixed codes.

Some other experts among other things Errington (1998), show that Javanese is getting to shift to bahasa Indonesia. This study is trying to show the vitality of Javanese in plurilingual societies in Karimunjawa. How Javanese as the biggest local language in Indonesia shows its strength not only in Java island but also in the islands spreading in Java sea like in regions as Karimunjawa where the societies are plurilingual. Who are the speakers of Javanese whether it is only spoken by Janese ethnic group or both Javanese and non-Javanese ethnic groups residing in Karimunjawa?. Whether it is still learned by the children whose parents are mixed marriage. Those questions will be explained in this paper.

Karimunjawa as one of the districts of Jepara regency consisting of 27 islands located in Java Sea of Central Java, Indonesia, is now resided by 4861 people of different ethnic groups among other things Javanese, Buginese, Bajonese, Mandarese, Wakatobinese, Butonese. The groups only inhabit five out of twenty seven islands namely, Karimunjawa, Kemujan, Nyamuk, Parang, Genting spreading. The ethnic groups orignally came from different regions of Borneo and Celebes and migrated to Karimunjawa for different reasons. They resided Karimunjawa since approximately the fifteenth century (Kesuma, 2004). 
Since they have lived in Karimunjawa for more than five centuries, they have blended with the settled community namely Javanese. The blend is shown by intercultural marriages, for example, Javanese marrying Buginese, Buginese marrying Maduranese, Maduranese marrying Javanese. The intercultural marriage builds intercultural families whose husband and wife speak different languages. Even they speak different languages with relatives.

Communication happens when the participants have mutual intelligibility or mutual comprehensibility (Stevens, 2008). Mutual intelligibility or comprehensibility can be built by shared knowledge and linguistic or sociolinguistic competence of the speakers. It may be built when speakers use the same code. By using the same code, the speakers have the same convention in labelling an entity talked about. In another word, they share the same knowledge of language in terms of form, meaning, and function. In this case, they share not only linguistic knowledge but also sociolinguistic one.

Since Karimunjawa as a stopover of the fishermen, in the beginning of their settlement in Karimunjawa they used local languages. According to Suliyati (2015) noone knew what year they migrated to Karimunjawa. She said, from her sources, the Buginese migrated to Karimunjawa since the fifteenth century. They become familiar with Javanese, and now they even use Javanese in their conversations among the family members and even outside homes.Buginese migrated to Karimunjawa due to some reasons namely internal conflict and better life.

Beside Javanese, Buginese is strong. Both languages, Javanese and Buginese are learned by their children. In addition, bahasa Indonesia is now learned by children. If in Javanese families, Javanese is learned, it is a normal situation, but if another language, that is bahasa Indonesia, is learned, it can affect Javanese existence. Then, how is the existence of Javanese among Buginese, Maduranese, Mandarese, Bajonese, Butonese, and Wakatobenese. This question will be investigated to show the existence of Javanese among plurilingual families in Karimunjawa. The aim of this research is to show the vitality of Javenese among the plurilingual individuals in Karimunjawa. Since plurilingual persons are found only in Karimunjawa, Central Java, this research is focused on Karimunjawa. This study is also focused on three islands namely Karimunjawa, Kemujan, and Nyamuk by considering availability, convenience, and event perspectives.

To study Karimunjawa, the writer will focus on the societies living in Kemujan, Karimunjawa, and Nyamuk islands due to their availability of the data. Parang and Genting haven't been explored yet due to time limitation and uniformity of the data based on the information gathered. Since the biggest population inhabit Kemujan and Karimunjawa, the study focuses on Kemujan and Karimunjawa, while Nyamuk is a place for confirmation. This study focuses on how the intercultural families communicate each other, what kind of communication patterns and the interactional discourse they have.

Karimunjawa has been studied by many experts with different perspectives like Rochwulaningsih et. al (2014; 2015) and Suliyati (2016). Rochwulaningsih (2015) studied Buginese in Karimunjawa from educational point of view, while Suliyati (2015) studied Karimunjawa from communication point of view. A study from linguistic perspective has not been found. This study focuses on Javanese that is used in plurilingual society in Karimunjawa. From the background, there are some questions raised namely how Javanese is used, in what 
domains it is used, how language acquisition happens, and what an interactional discourse is like. From these questions, the writer can present the purposes of the study namely to elaborate the domains Javanese is used, language acquisition happens in the plurilingual society, and the interactional discoursewhich happens in plurilingual families. This study is to see the vitality of Javanese surrounded by languages brought by the migrating fishermen among other things from Borneo, Celebes, and Madura.

To answer the research questions, the writer used some theories related to plurilingualism and multilingualism, language contact, and language maintenance or shift. Plurilingualism according to Council of Europe (2001) in Otwinowska-Kasztelanic (2012:38), refers to the ability of peopleinteracting with other people from different cultures, while multilingualism refers to someone's knowledge of different languages as they belong to a social group. This implies that plurilingual people will be automatically pluricultural in the sense that they understand the cultural values represented by the language they know.

Suliyati (2016) said that there is no clear sources mentioning when Buginese migrants settled in Karimunjawa, but based on some historical sources, according to her, Buginese migrated from the south Celebes to all regions in Indonesia in the fifteenth century due to internal conflict of the kingdoms of the south Celebes. The migration of Buginese to Karimunjawa occured approximately in the seventeenth and eighteenth centuries coming from Bone, Makassar, Wajo, Pinrang, Sidenreng Rappang (Kesuma, 2004). However, later, the migration for better life like the migration happened nowadays around forty-years ago.

Dealing with Javanese position in plurilingual societies, the writer is trying to study language vitality of Javanese. The studies on language vitality have been studied in different countries not only Indonesia but also Thailand like Tehan \& Markowski (2015) studying language vitality of So language, Thailand, and Malaysia like Mohamed \& (2012). They used Expanded Graded Intergenerational Disruption Scale (EGIDS) and the Sustainable Use Model (SUM) to evaluate So language of Thailand. Besides, they can predict the levels of the vitality of So language. Another study conducted by How Soo Ying, Chan Swee Heng, and Ain Nadzimah Abdullah (2015) assessing Malaysian languages consisting of Malay, Mandarin, Tamil, and English in order that they can show the vitality of each language in Malaysia. Another perspective of studying language vitality done by Ogone John OBIERO assessing African language endangerment and finding some effort to revitalize the language.

\section{MATERIAL AND METHOD}

To gather the data, the writer used observation to get the samples of conversation. The observation was conducted to get the conversation fragments taken happening at schools, homes, mosques, village chief's office, TPI (fish bidding place), and market. Besides, the writer used unstructured interview to ask the respondents depending on what is going on in the location the data were taken. For example, the topic discussedduring the conversation, what language is exposed to the children for the first time, who teaches first language, what parents' ethnic groups and language. If the conversation happened at the mosque, the topic chosen deals with the activity at the mosques and the function Javanese is used.

The other method used is questionnaire. The questionnares were distributed to the students of Safinatul Huda junior and senior high schools, especially whose parents are intermarried couples and willing to be interviewed. The availability and event principles were 
used in choosing respondents beside purposive one. The availability principle was used when the researcher asked the respondents about their willingness to be interviewed. However, the event principle was used when the researcher used the students of Safinatul Huda institution studying.

To analyze the data, the writer used referential and inferential methods. Referential method was used to indicate what language the speakers use in the conversations, while the inferential method was used to infer how language acquisition happens in the plurilingual families. Besides, the writer used translational method to show that the speakers of the same family using different languages can understand each other. Accordingly, the writer can identify what languages are used in plurilingual families.

\section{RESULT AND DISCUSSION}

Javanese in Karimunjawa can be said that it is still strong since the residences there can speak Javanese eventhough they are not Javanese. This implies that Javanese is still used and learned by the people who are plurilingual. The following explanation will show in what domains and functions Javanese is used, how Javanese is acquired in plurilingual families, and how vital Javanese is.

\section{Javanese Functions and Domains}

The functions of Javanese can be seen in five domains namely home, village chief's office, neighborhoods, markets, and mosques. In those five domains, Javanese is used. According to the informants they use Javanese since most of the people in Karimunjawa are Javanese. Even they do not only learn Javanese language but also Javanese traditions like wedding ceremoney. They do not learn the language but also the tradition.

Javanese at family domain can be seen from the language used in family members' communication. Javanese is used especially in families whose spouse is Javanese. For example, the village chief secretary, the Mandarese marrying Javanese woman, he uses Javanese more than Mandarese. This is supported by their answers given that they use Javanese due to some reasons; one of them is that most of peple living in Karimunjawa is Javanese and their spouse can not speak their language like Mr. X, the Wakatobinese, Mr. Y, the Buginese. When the writer interviewed the Buginese wife, she said that she could not speak Buginese, but her husband can speak Javanese very well.

Another case happens differently in an intercultural couple, Mandarese and Javanese. Mr. $\mathrm{Z}$, the Mandarese, married a Javanese woman, exposing bahasa Indonesia instead of Javanese to their son. The reason is that Javanese has more than one style, if they do not use properly, they will feel embarrased. Since the children use Javanese not in a proper style, they are worried if their son can not use Javanese properly especially when communicating with his grandparents. Javanese used at school domain must compete with bahasa Indonesia, especially in teaching and learning processes in the classroom. However, outside classroom, Javanese is used. This happens at kindergarten for very young children.Javanese is also used at village chief's office. Javanese is spoken not only by the officers but also the visitors, eventhough the officers are from different ethnic groups.

This domain depends on the majority of the ethnic groups. If they are Buginese they use Buginese. However, Javanese is also found, since the Javanese can not speak Buginese so that the Buginese is trying to suit his code when he communicates with others.Javanese used in 
Karimunjawa market can be seen in the market attendance's speech in offerring, bargaining, asking prices, for instance. Since most of the citizens are Javanese, people living there tend to use Javanese. In the market, there are many sellers selling daily needs like fish, rice, snack, for example, not only in a small scale but also in a large scale.

Javanese used at the mosque domain is used for dealing with public matters. For example, speeches in Friday prayers. The attendances are not only Javanese but also other ethnics. However, Javanese is used in giving speeches. Another example is when there was an Islamic event called Isro' Mi' ${ }^{7 i}$. Javanese was used by the village leader when delivering speech to welcome the audiences and open the ceremony. Javanese is also used for giving information when there was someone died. Javanese was used for informing it to all people of Karimunjawa. The information was delivered using microphone in order that it can be heard by people in distance. The announcement of someone's death happened when there was an accident in Kartini harbor when one of the people from Karimunjawa died. The announcement was delivered using microphone so everybody in Karimunjawa island could hear it. Eventhough, people living in Karimunjawa are not only Javanese but also Maduranese, Banjarese, Wakatobinese, for instance, the announcement was delivered in Javanese. This implies that only Javanese is used in the mosque. See the following example.

\section{Javanese Acquisition Process in Pluringual Families}

Javanese in plurilingual families is not only used but also learned. It is exposed to children through their caretakers. Javanese is exposed to children to make it learned and automatically to make it used and maintained. This happens not only in Javanese families but also in families with intercultural marriages, for example, Javanese marrying Buginese, or Wakatobinese, or Bajonese.

Javanese is learned as the first language by the children whose parents are mixed marriage. There are approaximately more than $30 \%$ of the respondents learning Javanese as the first language. This percentage does not only happen to the junior school students but also the senior high school ones. The acquisition is supported by the mothers' roles in exposing the language. For example, if the mother is Javanese, the children's first language is Javanese. However, when the mother is Buginese, for example, the children's language is Buginese. This supports Krashen's theory (1981), Steinberg\& Sciarini (2006) and invironmentalists' theory that language acquisition happens due to its environment. In addition, mothers are the closest environment for their children. It is contrary to the fact that fathers does not really affect their children's first language.

This is supported by the fact that the acquisition process runs well when non Javanese men marry Javanese women. They let their wife expose Javanese to their children. Since they leave home for earning money, they can not intensively teach their children. This matches the children's answer when asked from whom they learn their first language. This supports Krashen's theory (1981) concerning the five hypothesis that acquisation refers to unconscious learning that can make learning first language effective to make someone acquire first language effectively. The exposure is done in daily activities in fulfilling their needs like eating, drinking, sleeping, bathing, and playing. What happens, for example, before sleepingis that the mother 
tells a story, lullabies, sings songs. By doing so, the children absorb what the mother says and produces, then store the words or expressions in the mind. When needed, those are used in their speech.

That the non Javanese children from the mixed family that is Bau-bau and Javanese learn Javanese can be seen from the answer in the following fragment. Even the child participated in the conversation with Javanese. When asked whether he can speak Bau-baunese, he answered that he could not speak Bau-baunese. He did not learn Bau-baunese so that he could not speak Bau-baunese. Fortunately, his mother is Javanese. Therefore, he learns and can speak Javanese. In addition, he answered that his parents speak Javanese. This means that mixed families speak Javanese.

(1) File 160508_005

The setting was inMadrasah Diniyah(Islamic School)

Team : bapakmu saka ngendi?

Father SUFFIX from where

Where does your father come from?

A child: Bau-bau

Bau-baunese

Team :Ibumu asline ngendi?

MotherSUFFIX originCLITIC where

Where does your mother from?

A child: asli orang sini

Origin person here

She is from here (Karimunjawa)

Team : Kamu isa basa bau-bau?

You can language Bau-baunese

Can you speak Bau-baunese?

A child: nggak bisa

No can

'No, I can not'

Team :bapakmu karo ibukmu nganggo basa apa?

fatherSUFFIX motherSUFFIX use language what

'What language do your father and mother speak?'

A child:Jawa

Javanese

Team : kakakmu piro?

Brothers / sistersSUFFIX how many

'How many brothers/sisters do you have?'

A child: laki-laki dan perempuan

Male and female

In the conversation, in line [7], when he was asked what language his father and mother speak, he answered in line [8] that his parents speak Javanese. From the answer in line [2] he said that his father was from Bau-bau, the Celebes. It means that his father speaks Bau-baunese, while his mother speaks Javanese. Another example can be seen in the following fragment.

(2) Team : ini bapak ibuk kalau di rumah pakai bahasa apa?

This Sir Madam if at homr use language what?

'At home, what language do you use? Sir and Madam'

Lady : bahasa Jawa. Ya kadang bisa bahasa sulawesi. 
Language Javanese. Yes sometimes can language Celebes

Javanese. Sometimes, we can use Celebes language

Team : itu bahasanya bahasa apa namanya?

That language language what name?

'What language do they use?'

Lady : bahasa Bajo

'Bajonese'

if children taught what?

What language do you expose to your children?'

Man : Jawa

Javanese

Team : kenapa kok gak bahasa Bajo?

Why PART not language Bajonese?

'Why don't you teach them Bajonese?'

Lady : ya karena tetangganya kan banyak Jawa, temennya sekolah.

Yes since neighbour CLITIC TAG many Javanese friend Clitic school

'Since their neighbour are Javanese, and even their school mates.'

The fragment in (2) line (5) indicates that the intercultural families teach Javanese. When asked, kalau anak-anak diajarin apa? ( What language do you expose to your children?), the informants answered Javanese. The reason for teaching Javanese is that their neighborhood uses Javanese. In order to engage the language, they have to be able to speak Javanese.

\section{Javanese Vitality in Plurilingual Societies in Karimunjawa}

From the discussion in the previous subtopics supported by the following guidelines or questionnaire given by UNESCO, I may conclude that Javanese is still vital. The vitality can be seen from five points in the questionnaire. For example, From observation and recording techniques, I have experienced that Javanese was used or spoken by parents and children, among friends, and even people in the market and mosques. The vitality is supported not only by Javanese speakers but also non Javanese speakers. The following is the fragment taken randomly in a public place that is a place where parents are waiting for their children learning to read the Quran, usually called Ngaji. It was taken in Kemujan island in the afternoon.

(3) File (10010101) Anak Ngaji Sore in

(4) Kemujan

Pasar tebih, pasare wedi srengenge jam pitu pun lebar.

Market far, market afraid sun hour seven finish

'The market is far. It is finished at seven when the sun has been rising'.

Lady :Angsal iwak kula sade ten bakul. kula sing mancing.

Get fish I sell to seller I who fish

'When I get fish, I sell it to a fish seller. I fish myself'

Team : Nek mancing mangkate jam pinten mbak?

If fish go time what sister

'If you go fishing, what time do you leave for fishing, Ms?'

Lady : Isuk. Mancing tengiri ngagem bukbuk [bUgbUg] (kerangkeng iwak).

Morning. Fish tengiri with bukbuk cage fish

In the morning. I fish with bukbuk -a kind of fish trapper. 
Dipasang, iwake masuk dewe, dikrangkeng.

Install fish enteritself in cage

'When the trapper is put, the fish will enter the trapper'

The conversation runs smoothly, see the appendix. There are some more examples taken in different domains, but they are in Javanese. The fragment (1) was taken randomly and spontaneously without any appointment with the persons targetted.The conversation is in Javense. All the linguistic units used are Javanese, even the function words.

The use of Javanese can be seen in ceremonies or ritual. According to the informantion, the use of bahasa Indonesiamay affect Javanese in terms of language contact that may result in Javanese to shift to bahasa Indonesia.

\section{CONCLUSION}

From the explanation, it can be concluded that Javanese in plurilingual societies ofKarimunjawa is still vital.Javanese is used in six domains with its functions and characteristics. From the study, it can be seen that the use of bahasa Indonesia is adjacent to the use of Javanese. Eventhough there are many ethnic groups in Karimunjawa, Javanese is still strong. It is characterized that Javanese is still learned by young generation with krama -the higher style. When a language is still learned, it is still used by young generation. However, Javanese has to compete not only with the migrant languages but also with bahasa Indonesia. The following research can be done for looking at the vitality of the migrant languages in Karimunjawa.

\section{REFERENCES}

Errington, J. Joseph. 1998. Shifting Languages Interaction and Identity in Javanese Indonesia. Cambridge: Cambridge University Press

Kesuma, Andi Ida. 2004.Migrasi dan Orang Bugis. Yogyakarta: Penerbit Ombak.

Krashen, Stephen D. 1981(2002 internet edition). Second Language Acquisition and Second Language Learning. Pergamon Press, Inc.

Krippendorff, Klaus. 2004. Content Analysis: An Introduction to Its Methodology. California: Sage Publications, Inc.

Mohamed, Noriah \& Nor Hashimah Hashim. 2012. "Language Vitality of the Sihan Community in Sarawak, Malaysia”. Kemanusiaan Vol. 19, No. 1, (2012), 59-86

Otwinowska-Kasztelanic, Agniesteinbergszka. 2012.”Plurilingualism and Polish Teenage Learners of English". LINGVARVM ARENA - Vol. 3 ANO 2012. Pp 37-52 http://ler.letras.up.pt/uploads/ficheiros/10948.pdf diakses pada hari Senin, 1 Mei 2017 pukul 15.55

Purwoko, H. 2011. If Javanese is Endagered, How Should We Maintain It? Paper presented at the International Seminar Language Maintenance and Shift, Semarang, Indonesia. Retrieved from https:// core.ac.ukdownload/pdf/11735727.pdf

Rochwulaningsih, Yety, Singgih Tri Sulistiyono, Noor Naelil Masruroh. 2014. "Pattern of Center Periphery Relationship in Small Islands: A Case Study in Karimunjawa Islands, 
Indonesia”. International Journal of Marine Science, Vol.4, No.22 197-209 (doi: 10.5376/ijms.2014.04.0022)

http://biopublisher.ca/index.php/ijms/article/view/1254/1131 diakses pada hari Senin, 1 Mei 2017 pukul 17.20

Rochwulaningsih, Yety. 2015. "The Role of Social and Cultural Values in Public Education in Remote Island: a Case Study in Karimunjawa Islands, Indonesia”. Jurnal komunitas 7 (1) (2015):25-36.

DOI:10.15294/komunitasv7/iI.3336https://docs.google.com/viewerng/viewer?url= https://journal.unnes.ac.id/nju/index.php/komunitas/article/viewFile 13336/pdf 16 diakses pada hari Senin, 1 Mei 2017 pukul 16.48

Steinberg, Danny D \&Natalia Sciarini. 2006. An Introduction to Psycholinguistics. Malaysia:Longman

Stevens, Amanda. (2008). "A Way of Knowing: Tools and Strategies for Managing Indigenous $\begin{array}{lllll}\text { Knowledge”. in Libri, } & \text { vol }\end{array}$ http:// citeseerx.ist.psu.edu/viewdoc/download?doi=10.1.1.620.728

\&rep=rep1\&type $=$ pdf retrieved on Sunday, March 6, 2016 at 21.19

Suliyati, Titiek. 2016. "Etnis Bugis Di Kepulauan Karimunjawa: Harmoni dalam Pelestarian Budaya dan Tradisi” Sabda, Volume 11, Tahun 2016

Tehan, Thomas M \& Linda Markowski. 2017. "An Evaluation of So Language Vitality in Thailand". Journal of the Southeast Asian Linguistics Society JSEALS Vol. 10.1 (2017): 45-66 ISSN: 1836-6821, DOI: http://hdl.handle.net/10524/52397 University of Hawai'i Press. Pp 45-66

UNESCO. No dates. UNESCO Survey: Language Vitality and Diversity file:///D:/LANGUAGE\%20VITALITY/Unesco Vitality Diversity \%20Questionnair e1.pdf

Ying, How Soo, Chan Swee Heng, Ain Nadzimah Abdullah (2015). "Language Vitality of Malaysian Languages and its Relation to Identity". GEMA Online ${ }^{\circledR}$ Journal of Language Studies Volume 15(2), June 2015. Pp 119-136. 